\title{
ДЕТСКАЯ ОДЕЖДА КАК СРЕДСТВО ВОСПИТАНИЯ В РУССКОЙ НАРОДНОЙ ПЕДАГОГИКЕ МЛАДЕНЧЕСТВА
}

\section{CHILDREN'S CLOTHING AS A MEANS OF EDUCATION IN THE RUSSIAN FOLK PEDAGOGY OF INFANCY}

\section{A. Izmailova}

Summary: The article examines the tradition of Russian folk pedagogy of infancy, associated with children's clothing. Clothing is considered as a means of aesthetic, moral, physical and Orthodox education in Russian folk pedagogy. The items that make up the complex of everyday and festive clothing of the baby in Russian folk pedagogy are indicated. The attitude to clothing in children is brought up on the principle of care in Russian folk pedagogy. To educate children about the careful attitude to clothing, numerous methods and means of Russian folk pedagogy are used. Clothing is both a subject of material and spiritual culture of the Russian people. Based on examples from numerous literary sources, the ideas about children's clothing that existed in Russian folk pedagogy for centuries are recreated.

Keywords: education and training in Russian folk pedagogy, methods and means of Russian folk pedagogy, virtues and vices, dress code.

\author{
Измайлова Алла Борисовна \\ К.п.н., дочент, Владимирский государственный \\ университет имени А.Г. и Н.Г. Столетовых \\ aismylove@yandex.ru
}

Аннотация: В статье исследуется традиция русской народной педагогики младенчества, связанная с детской одеждой. Одежда рассматривается как средство эстетического, нравственного, физического и православного воспитания в русской народной педагогике. Обозначены предметы, составляющие комплекс будничной и праздничной одежды младенца в русской народной педагогике. Отношение к одежде у детей воспитывается на принципе бережи в русской народной педагогике. Для воспитания у детей бережного отношения к одежде используются многочисленные методы и средства русской народной педагогики. Одежда является одновременно предметом материальной и духовной культуры русского народа. На основе примеров из многочисленных литературных источников воссозданы представления о детской одежде, бытовавшие в русской народной педагогике на протяжении веков.

Ключевые слова: воспитание и обучение в русской народной педагогике, методы и средства русской народной педагогики, добродетели и пороки, dress code.

ствовала сплочению всех братьев и сестер в семье, воспитанию у них единства и родственных чувств.

Первая носильная рубашечка младенца, как известно, имеет особый покрой и называется «запашонка - распашонка, запашная рубашечка младенца» [1, т. 1, с. 613]; «распашонка - детская рубашонка, спереди во всю длину разрезанная» $[1$, т. 4, с. 66].

Обычно распашонка шьется очень короткой и доходит только до поясницы (чтобы не пачкалась). По этой одежде маленького ребенка в шутку называют «пузаном», поскольку его животик в распашонке остается обнаженным. Именно о такой рубашке говорится в перевертыше как средстве русской народной педагогики: «Одерни пуп, рубаху видно!» [2, с. 454].

Первую одежду ребенку (как и пеленки) шили только из старой, ношеной ткани. Объяснений этому древнему обычаю существует несколько. Во-первых, это было связано с принципом бережи, для воспитания у ребенка бережливости. Во-вторых, считалось, что сшитая из старой материнской или отцовской рубахи одежда магически [3, с. 341] защитит ребенка родительской силой, которой ткань напиталась за время носки. В-третьих, этот обычай имел гигиенический характер, поскольку, как уже отме- 
чалось, ношеная ткань более мягкая и не раздражает нежную кожу ребенка («Новая рубаха тело дерюжит, а обносится - шелковая» [1, т. 1, с. 432].

Одевание младенца в русской народной педагогике рассматривается как повод для общения с ним и вызывает у любящей матери прилив нежности, она радостно разговаривает с малышом, нередко облекая свои чувства в ритмическую форму. Одевая младенца, мать напевает при этом песенку, часто собственного сочинения: «"Рубашонка, шонка, шонка, / Рубашоночка! / Распашонка, шонка, шонка, / Распашоночка! / Для миленка, для дитенка, / Для дитеночка!" / Так выкрикивала ночью у меня за стеной жена управдома, восхваляя новую рубашку своего грудного младенца» $[2$, с. 536].

В теплое время года рубашечка для младенцев обоего пола была единственной одеждой. В случае необходимости к первой рубашечке могли добавить вторую.

Отправляя младенца на прогулку, воспитатели руководствовались погодными условиями, при этом дети часто были одеты довольно легко, на взгляд современных воспитателей (ранней весной «ребятишки с утра до ночи в одних рубашонках играют на пригреве солнышка, и только морозец к вечеру и голос матери, зовущий ужинать, засветло загоняет их в избу» [4, с. 25]).

Такое закаливание с самого раннего детства защищало от простуды, поэтому нередко ребенок выбегал ненадолго из теплой избы босиком, прыгая по уже замерзшим кочкам, без всякого вреда для своего здоровья.

Правильный выбор одежды способствует физическому воспитанию в традиции русской народной педагогики, а прохлада заставляет детей много двигаться на свежем воздухе, участвуя в различных подвижных играх.

Если в помещении было тепло, то часть одежды с младенца снимали, при этом более опытный воспитатель давал указания матери или няньке («Разболоки ребенка, жарко в избе» [1, т. 4, с. 15]; «Раздень ребенка» [1, т. 1, с. 509] и т.п.

Чрезмерное укутывание считалось нецелесообразным, могущим нанести ущерб здоровью ребенка, и на это неопытным воспитателям также укоризненно указывали («Целый воз одежи накутали на ребенка» [1, т. 2, с. 431]; «Кутаться без нужды - баловство» [1, т. 1, с. 43] и т.п.).

Если воспитатели продолжали укутывать малыша, то другие дети могли применить к нему метод насмешки («Укуталась клушей, оделася кувалдой» [1, т. 4, с. 486]; «Оделася клушей, окуталась кувалдой» [1, т. 2, с. 121]; «Ворочается, кувалда кувалдой!» [1, т. 2, с. 210] и т.п.).
Негативное отношение к излишней одежде подтверждает, что в русской народной педагогике сложились определенные стандарты в одежде для младенца, говоря современным языком, своего рода dress code.

К первой носильной рубашечке младенца на сороковой день от роду добавлялся пояс. Впервые ребенка подпоясывала крестная мать, которая «приносила ему в подарок поясок, рубашку, крестик» [5, с. 104-105]. Пояс рассматривался как оберег, считалось, что «подпоясанного человека "бес боится", его не тронет ни домовой, ни леший» [6, с. 321-322].

Обычай своевременного подпоясывания младенца неукоснительно исполнялся в русской народной педагогике младенчества. Считалось, что «не опоясанный ребенок может умереть» [7, с. 119], так как пояс был и оберегом младенца от болезней.

В некоторых местностях России ребенка впервые подпоясывали позднее. «Крестная подпоясывала ребенка, когда ему исполнялся год, поставив предварительно к печному столбу и приговаривая при этом следующее благопожелание [8]: “Будь здоров и толстой, как печной столб"» $[5$, с. 105].

Такая отсрочка первого опоясывания была связана с запукой [9] как методом русской народной педагогики, которая объясняла, что «ребенка не опоясывали до года, "чтобы не запоясать роста и прорезывания зубов"» [10, c. 516].

Положительное значение пояса в русской народной педагогике подтверждается бытованием дразнилок («Афанасьи беспоясны - дразнят не носящих опояски по рубахе» [1, т. 1, с. 32]), направленных против «беспоясных». Это объяснялось тем, что «по русским поверьям, ходить без пояса было так же "грешно", как и без креста» $[11$, c. 231].

Пояс был зачастую единственным украшением («На поясах узор очень сложен, орнамент разных цветов как бы вкладывается один в другой. Ромбы, круги <...> имели значение амулетов» [11, с. 233]) будничной одежды.

Интересно отметить, что в XIX веке были повсеместно распространены «пояса и опояски “со словесами"» [11, с. 235]. Текст мог быть молитвой или посвящением носителю. Считалось, что такие надписи вдоль пояса усиливают его обережную функцию и превращают пояс в памятный и дорогой подарок от любящего человека. Кроме того, эти тексты могли служить первоначальным наглядным пособием при обучении детей грамоте.

Такие пояса сочетали в себе воспитательные возможности и как предмет материальной культуры, и как эле- 
мент духовной культуры русского народа. С помощью красивого пояса в русской народной педагогике осуществлялись различные направления воспитания (эстетическое, нравственное, умственное, православное).

Позднее детские пояса упрощаются («Служили для пояска обыкновенные тесемочки или плетенные из красных шерстяных ниток шнуры» [12, с. 280]).

Надевая на младенца рубашку и подпоясывая его поясом, мать или бабушка не забывали загадать ему загадки («Днем обручем, ночью змеей», «Надену - ободом сведет, / Сойму - змеей упадет, / Тепла не дает, а без него холодно (Пояс)» [13, с. 122]; «Один вход, три выхода» «Собой не однака, а нужна одинако / Младенцу, и мертвецу, / И доброму молодцу (Рубашка)» [13, с. 121]) об этих предметах одежды, что также вносило элементы игры и сказочной традиции в процесс общения при одевании. Кроме того, загадки об одежде служат средством умственного воспитания в русской народной педагогике.

Так, в рубашке с пояском, ребенок и ходил все младенчество. Затем к рубашке добавлялся такой вид одежды, который определял пол ребенка. При переходе в отрочество, в «6-8 лет мальчику одевали штаны, а девочке - юбку» [5, с. 106], хотя зачастую сроки переодевания ребенка в новую одежду зависели от достатка семьи. «Установить, с какого возраста одевают детей приличнее, трудно. Есть дома, обычно богатые, где на ребенка с 4-5 лет надевают пиджак и шерстяную рубаху, в то время как в других домах дети могут до 15 лет носить затрапезную одежду. Впрочем, таких случаев много меньше, чем первых. Одни начинают одевать детей начиная со школьного возраста, с 8-9 лет, другие - с выходом из училища, с 12-13 лет (таких большинство)» [14, с. 221]; «Девочкам шьют ситцевые платья и казинетовые пальто или жакетки» $[14$, с. 219].

Одежда в русской крестьянской среде была обязательным компонентом повседневной действительности, без нее нельзя было даже спать (ребенка предупреждали: «Никогда не спи нагишом, ибо сон смерти брат, преддверие к Страшному суду Господню. Надо быть всегда в готовности, одетым в дорогу» $[15$, с. 214]).

При шитье одежды воспитатели старались готовить обновки одновременно всем детям в семье, чтобы среди них не было обид («Всех ребятишек обкроила, по рубашке на брата» [1, т. 2, с. 590]). Особенно часто приходилось обновлять детскую одежду после лета («Пообшить надо ребятишек, все за лето оборвались» [1, т. 3, с. 291]), поскольку дети сильно вырастали под теплым солнышком, на ягодах и других летних лакомствах, а кроме того, одежда быстро изнашивалась в подвижных играх и летних прогулках.
Одежда часто выступала подарком к праздничному дню («Новая одежда нашивается к Пасхе» [14, с. 266]).

Всякий новый наряд воспринимался ребенком как праздничный, потому что впервые обновку надевали на праздник. Ребенок учился «радоваться подарку, привыкая к бережному любовному отношению к одежде. В больших семьях обновы вообще были не очень часты. Одежда (реже обувь) переходила от старшего к младшему. Донашивание любой одежды считалось в крестьянской семье просто необходимым. <...> Выбрасывать считалось грехом, как и покупать лишнее» [16, с. 195].

Как уже отмечалось, русская народная педагогика воспитывала представления о бережи, распространявшиеся на все предметы материального мира. Для детской одежды этот принцип реализовывался в изготовлении ее из лоскутков, остававшихся от кроя взрослой одежды. Позднее такие лоскутки («лепестье») покупались на вес на текстильных фабриках. Изготовление лоскутной одежды давало простор фантазии и позволяло народным мастерицам создавать настоящие шедевры портновского искусства.

Дети быстро росли, поэтому детскую одежду шили чуть большего размера, особенно праздничную, которая изготовлялась из более дорогой ткани («Одежа сшита на вырост (для ребенка, с запасом)» [1, т. 1, с. 310]; «Вася в шелковой, мешковато на нем сидящей, "на вырост" шитой рубахе, по вороту которой вьется едва заметная вышивка» [17, с. 281] и др.).

При первом надевании новой одежды использовался метод благопожелания, с помощью которого поздравляли человека с обновкой, желали наряду прочности, а человеку - успешного движения по жизни («С обновочкой: дай Бог носить, носить, не изнашивать!» [1, т. 2, с. 537]; «Дай Бог износить (обнову), да лучше нажить» [1, т.2, с. 413]; «Обновить девицей, износить молодицей!» [18, с. 110]; «Чтобы платьице тонело (обнова), а хозяюшка его добрела» [1, т. 4, с. 415]; «Одежде пропадать, на плечах бы тлеть, а могучим плечам добреть да добреть!» [1, т. 2, с. 337] и др.).

Помимо календарных праздников, обновки детям готовили и к другим памятным датам (к именинам, а позднее - к дню рождения), о чем ребенку сообщали заранее («Сошью я к именинам штаны» [19, с. 85]»). Новая рубашка была традиционным подарком на именины от крестной матери, что подтверждает соответствующая прибаутка: «Тетка-божатка, / Сошей мне рубашку, / Тоненьку, беленьку, / Косой вороток» [20, с. 107]).

В этой прибаутке отразились народные представления о нарядной рубашке, которая должна быть вышитой косовороткой из тонкой белой ткани. 
Примерка обновки становилась значимым моментом в жизни младенца, поскольку этому событию радовались все его родные и близкие, а особенно - тот, кто ее сшил. Под влиянием положительных эмоций окружающих и сам ребенок приходил в радостное настроение, слушая ласковые слова матери, о детской сорочке - «бобе, бобке» $[1$, т. 1, 100]: «А вот бобаньку наденем новенькую» [1, т. 1, 100].

Младенца одевали мать или бабушка, используя при этом игру, что развлекало ребенка, превращало обыденное действие в интересное занятие («Одевают ребенка - приговаривают: "Ножка-ножка, полезай в окошко" (в чулочек, трусики). Если ребенок действует неловко: “Ручка-озорнучка, ты слушай Катю". Обувают: “Ботинок, ты правильно стой"» [21, с. 71]).

В русской народной педагогике одежда различалась в будни и праздники, что подчеркивалось и ее особыми наименованиями. Будничная одежда называлась "ходильная» [1, т. 4, с. 557], а праздничная - «христовник праздничная одежда, кафтан, шелковый сарафан и пр.» $[1$, т. 4, с. 565].

Существование особых наименований одежды имело и воспитательное значение, так как даже младенец, надевая праздничную одежду, понимал, что сегодня особый, небудничный день, когда и вести себя следует по-особому.

Праздничная одежда отличалась от будничной украшениями. Хотя детская одежда традиционно не украшалась, но обережные знаки допускались («На мальчиках были кремовые шелковые рубашки, расшитые "русским" крестиком внизу и на рукавах широкой пестрой полосой. Бабушка Зоя со мной всю зиму трудилась над этими вышивками, уж очень нам хотелось нарядить наших мальчуганов» [22, с. 197]).

Расшитая рубашка создавала радостный настрой, помогала ощутить торжественность праздничного дня, а также давала возможность восхищаться мастерством материнских рук («На мне была белая вышитая рубашка, подпоясанная афонским пояском. На мою рубашку все смотрели, и какая-то барыня сказала другой: / - Чудесная русская вышивка! / Я был счастлив за свою мать, которая вышила мне такую ненаглядную рубашку» [15, с. 20]).

Детская одежда продолжала оставаться очень скромной и в первой половине XX в. («На праздники из новенького пошьешь, ну там тесемочка, цветок с листиками вышьешь для форсу» [12, с. 279]).

Самым любимым в русской народной одежде был красный цвет, символизировавший животворящие силы природы [11, с. 238], и потому праздничные рубахи и сарафаны были из красной ткани, что подтверждают русские народные сказки (отец обещает дочерям: «Которая перва наберет ягод скорее, то той я куплю кумашный (кумачовый) сарафан и беленький платочек» [23, с. 172]) и колыбельные песни («Ходит Сон по лавочке / В красненькой рубашечке» [24, с. 245]).

При большом скоплении народу на праздничном гулянье разодетые в яркие наряды крестьяне выглядели очень живописно (Крестьяне <...> любят употреблять в обилии красный цвет во всем, что касается до наряда» [4, с. 137]; «Можно было разглядеть и ребятишек, играющих на траве в красных рубашонках и синих сарафанишках» [25, с. 121] и др.).

Как уже отмечалось, одежду для младенца приготоавляли заботливые руки матери, и при этом каждый проложенный по ткани стежок сопровождался методом благопожелания, средствами реализации которого были доброе слово и молитва, исходящие из любящего материнского сердца.

Дети много играли, бегали, и потому их одежда быстро пачкалась («Ребятишки в грязи пластаются» [1, т. 3, с. 121]; «Повыпачкались ребятишки сами в грязи и всю одежду на себе повыпачкали» [1, т. 3, с. 149] и т.п.).

Обычно воспитатели предупреждали детей перед прогулкой о необходимости быть аккуратными («Не чупкайся по грязи, зачупкаешь платье!» [1, т. 4, с. 615]).

В не очень благополучных семьях детей «в будни одевают, как правило, в рваную и грязную одежду, старое платье» [14, с. 266], полагая, что ребенок все равно испачкается, и незачем тратить силы на стирку его одежды. Грязный, неприбранный ребенок («Ребенок этот вовсе запущен» $[1$, т. 1, с. 624]; ребенок «нечисто ходит - неопрятно» [1, т. 2, с. 543]) производил удручающее впечатление на соседей, заставляя предполагать, что ребенка не любят. Подтверждение этому находим в зачинах сказок (старших братьев «баба любила, чисто одевала; а последний завсегда был одет худо - в черной сорочке ходил» $[26$, с. 253]), где читатель сразу же вводится в атмосферу рассматриваемой семьи.

К неприбранному ребенку применялись соответствующие методы (упрек, насмешка) и средства (дразнилки) русской народной педагогики младенчества, что можно рассматривать и как косвенное воздействие на его родителей. Наиболее часто неаккуратных в носке одежды и неопрятных называли «неряхами» («Хоть в шелк одень неряху, всё глядеть не на что» [1, т. 2, с. 534]; «“Алеша, подвяжи (подбери) калоши (здесь «калоши» - детские штанишки. - А.И.)!" - дразнят неряху» [1, т. 2, с. 79] и др.). 
Однако все понимали, что в своем неприглядном виде виноват не ребенок, а его мать, которую соседи заслуженно именовали «лентяйкой», «неряхой» и т.п.

Следует отметить, что заботливые и опрятные матери и бабушки старались держать ребенка «чистенько», хотя это и стоило им многих трудов. Именно чистоте и аккуратности в русской народной педагогике придавалось первостепенное значение, а не новизне и дороговизне одежды. Поддержание опрятности в одежде воспринималось в русской народной педагогике младенчества как важное средство нравственного воспитания (таких добродетелей, как аккуратности, бережливости, достоинства, самоуважения и др.).

Воспитатели старались не бранить малыша, испачкавшего одежду, а объяснить, как легко ее загрязнить, и показать, как трудно сделать ее снова чистой. Девочек с малых лет приучали помогать матери при стирке белья.

Воспитанию бережного отношения к одежде способствовало и то, что ребенок с самых ранних лет наблюдал, как много работает его мать, чтобы одеть всю семью. Выращивание и обработка льна занимала много времени, и воспитатели помогали детям осмысливать этот процесс с помощью сказок (например, сказка К.Д. Ушинского
«Как рубашка в поле выросла»).

С помощью различных методов и средств русской народной педагогики младенчества воспитатели приучали ребенка ценить труд близких людей, не придавать им лишних хлопот с одеждой.

Таким образом, подводя некоторые итоги нашего рассмотрения традиции русской народной педагогики младенчества, связанной с детской одеждой, можно сделать следующие выводы. Одежда рассматривалась не только как средство защиты тела, но и как средство воспитания души младенца. С этой целью детская одежда использовалась в таких направлениях воспитания в русской народной педагогики, как эстетическое, нравственное, физическое, православное, умственное. Отношение к одежде воспитывалось у детей на принципе бережи как одном из основных принципов русской народной педагогики. Нравственное отношение к одежде обнаруживало добродетели ребенка, которые народные воспитатели формировали с помощью разнообразных средств и методов русской народной педагогики. Традиция русской народной педагогики младенчества обеспечивала ношение детской одежды в соответствии c dress code, а следовательно, и сохранение гармонии человека с окружающей средой.

\section{ЛИТЕРАТУРА}

1. Даль, В.И. Толковый словарь живого великорусского языка: в 4 т. / В.И. Даль. - М., 1978-1980.

2. Чуковский, К.И. От двух до пяти // Чуковский К.И. Стихи и сказки. От двух до пяти. - М., 1981. - С. 267-596.

3. Семенова, М. Мы - славяне! / М. Семенова. - СПб., 1997. - 560 с.

4. Селиванов, В.В. Год русского земледельца / В.В. Селиванов // Письма из деревни / сост. Ю.В. Лебедев. - М., 1987. - С. 24-145.

5. Маслова, Г.С. Народная одежда в восточнославянских традиционных обычаях и обрядах XIX - начала XX в. / Г.С. Маслова. - М., 1984. - 216 с.

6. Плотникова, А.А. Пояс / А.А. Плотникова // Славянская мифология: энциклопедический словарь. - М., 1995. - С. 321-322.

7. Приметы и суеверия. - М., 1997. - 400 с.

8. Измайлова, А.Б. Благопожелание как метод русской народной педагогики / А.Б. Измайлова // Вестник ВГПУ. - Владимир, 2002. - Вып. 7. - С. 69-73.

9. Измайлова, А.Б. Феномен запуки в традиционной русской педагогике / А.Б. Измайлова // Педагогика. - 1997. - № 6. - С. 98-102.

10. Листова, Т.А. Обряды и обычаи, связанные с рождением детей. Первый год жизни / Т.А. Листова // Русские: монография / отв. ред. В.А. Александров. М., 1999. - С. 500-517.

11. Лебедева, А.А. Значение пояса и полотенца в русских семейно-бытовых обычаях и обрядах XIX-XX вB. / А.А. Лебедева // Русские: семейный и общественный быт. - М., 1989. - С. 229-248.

12. Науменко, Г.М. Этнография детства / Г.М. Науменко. - М., 1998. - 390 с.

13. Загадки / сост. В.В. Митрофанова. - Л., 1968. - 255 с.

14. Быт великорусских крестьян-землепашцев. Описание материалов этнографического бюро князя В.Н. Тенишева (на примере Владимирской губ.) / авт.сост. Б.М. Фирсов, И.Г. Киселева. - СПб., 1993. - 472 с.

15. Никифоров-Волгин, В.А. Дорожный посох: избранное / В.А. Никифоров-Волгин. - М., 1992. - 368 с.

16. Белов, В.И. Лад: очерки о народной эстетике // Белов В.И. Избр. произведения: В 3 т. - М., 1984. - Т. 3. - С. 3-326.

17. Астафьев, В.П. Сорока // Астафьев В.П. Последний поклон: повесть. - В 2 т. - М., 1989. - Т. 2. - С. 280-311.

18. Громыко, М.М. Мир русской деревни / М.М. Громыко. - М., 1991. -450 с.

19. Астафьев, В.П. Монах в новых штанах // Астафьев В.П. Последний поклон: повесть. - В 2 т. - М., 1989. - Т. 1. - С. 76-109.

20. Мудрость народная. Жизнь человека в русском фольклоре. - М., 1991. - Вып. 1. Младенчество. Детство. - 589 с

21. Палагина, Н.Н. Развитие воображения ребенка в русской народной педагогике / Н.Н. Палагина // Вопросы психологии. - 1989. - № 6. - С. 69-73.

22. Соколова, Н.Н. Под кровом Всевышнего / Н.Н. Соколова. - М., 1999. - 464 с. 
23. Детская // Кума-Чародейка. - Н. Новгород, 1993. - С. 172-173.

24. Русская народная поэзия: лирическая поэзия / сост. Ал. Горелов. - Л., 1984. - 584 с.

25. Солоухин, В.А. Колокол // Солоухин В.А. Смех за левым плечом. - М., 1989. - С. 120-130.

26. Летучий корабль (№ 144) // Народные русские сказки А.Н. Афанасьева: в 3 т. - М., 1984. - Т. 1. - С. 253-256.

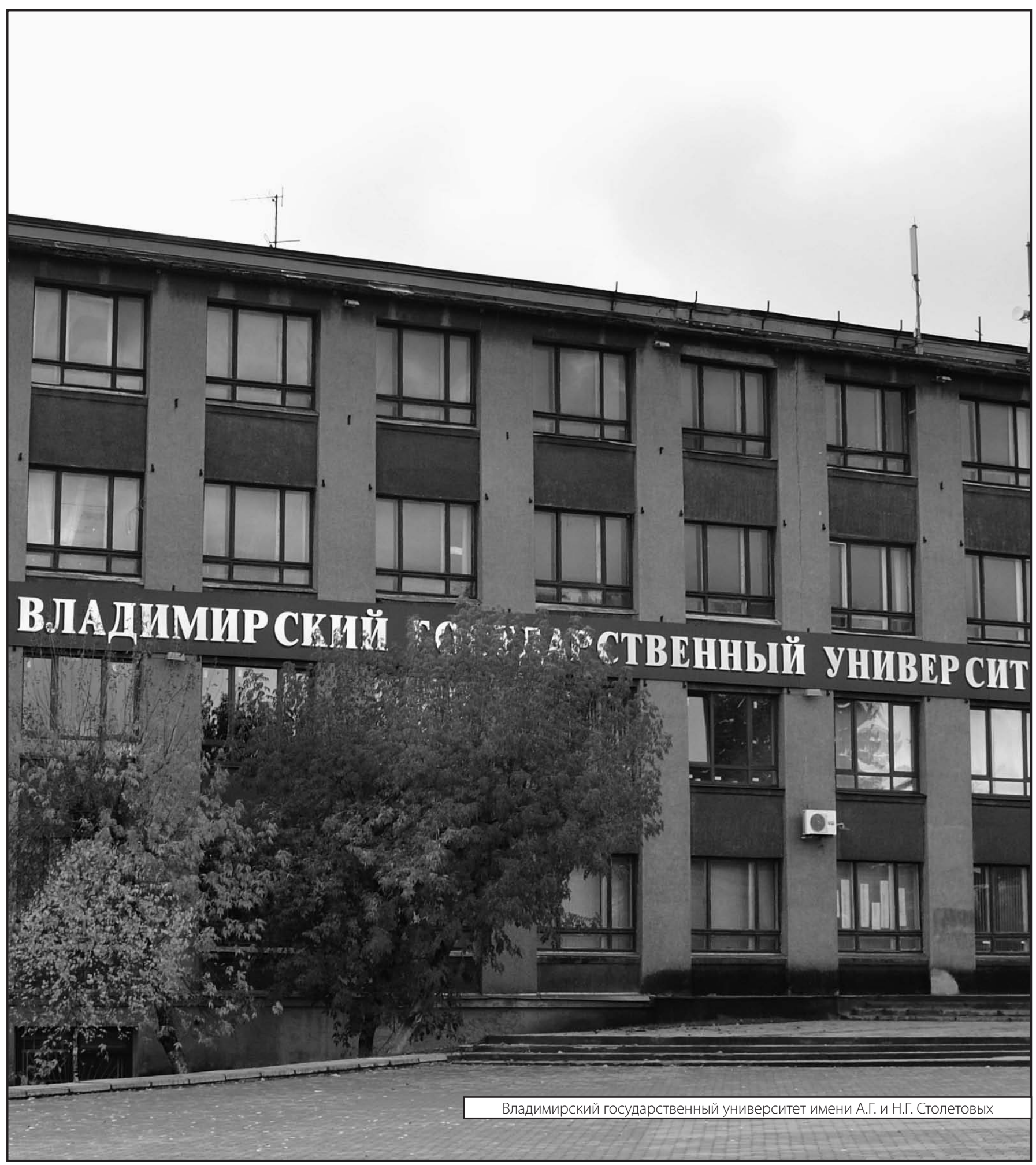

